\title{
URGENSI PENERAPAN CALESTIAL MANAGEMENT BAGI PENINGKATAN KUALITAS SDM PADA IKNB SYARIAH
}

\author{
Trimulato \\ Dosen Perbankan Syariah Universitas Muhammadiyah Parepere \\ Email:trimsiuii@yahoo.co.id
}

\begin{abstract}
The non-bank syariah financial industry (IKNB Syariah) in Indonesia continues to experience a very good improvement. The growth of IKNB Syariah is seen in the total assets of IKNB syariah in 2010, 9,333 billion rupiah, in year rose to 46,895 billion rupiah. With an average growth rate of $62.29 \%$. Therefore, the development of IKNB syariah must be balanced with sufficient resources and quality. OJK efforts have been made in improving the quality of human resources in IKNB Syariah with two big strategies. This research uses a qualitative descriptive type, Limitation in this paper is focused on OJK efforts in improving the existing human resources IKNB syari'ah. The need for application of celestial management for human resources in IKNB syariah. The results of this paper that OJK has set two strategies in an effort to improve the quality of human resources in IKNB sharia. Then the need for application of celestial management for human resources in IKNB sharia to create good quality. Because IKNB sharia is a business institution that can not be separated from religious or spiritual aspect. So it requires the right concept in improving the quality of human resources it has.
\end{abstract}

Keywords: IKNB Syari'ah, Human Resources, and Calestial Management

\begin{abstract}
Industri keuangan syariah non bank (IKNB Syariah) di Indonesia terus mengalami peningkatan yang sangat baik. Terlihat pertumbuhan IKNB Syariah terlihat pada jumlah aset IKNB syariah pada tahun 2010, 9.333 milyar rupiah, pada tahun naik menjadi 46.895 milyar rupiah. Dengan tingkat pertumbuhan rata-rata 62,29\%. Maka dari itu perkembangan IKNB syariah harus diimbangi dengan sumber daya yang mencukupi dan berkualitas. Telah dilakukan upaya dari OJK dalam meningkatkan kualitas sumber daya manusia pada IKNB Syariah dengan dua strategi besar. Penilitian ini menggunakan jenis deskriptif kualitatif, Batasan dalam tulisan ini difokuskan pada upaya OJK dalam meningkatan sumber daya manusia yang ada IKNB syari'ah. Perlunya penerapan celestial management bagi sumber daya manusia pada IKNB syariah. Hasil dari tulisan ini bahwa OJK telah menetapkan dua strategi dalam upaya meningkatkan kualitas sumber daya manusia pada IKNB syariah. Kemudian perlunya penerapan celestial management bagi sumber daya manusia pada IKNB syariah untuk menciptakan kualitas yang baik. Karena IKNB syariah adalah lembaga bisnis yang tidak terlepas dari aturan agama atau aspek spiritual. Sehingga membutuhkan konsep yang tepat dalam meningkatkan kualitas sumber daya manusia yang dimilikinya.
\end{abstract}

Kata Kunci : IKNB Syari'ah, Sumber Daya Manusia, dan Calestial Management

\section{PENDAHULUAN}

Industri keuangan syariah di Indonesia memiliki potensi untuk terus bertumbuh dan memiliki kemanfaatan yang besar bagi perekonomian. Industri Keuangan Non-Bank 
(IKNB) yang berbasis syariah pun menjadi satu pilar kekuatan di industri keuangan syariah, yang perkembangannya diharapkan bisa ikut menumbuhkembangkan perekonomian syariah di Indonesia. IKNB Syariah adalah bidang kegiatan yang berkaitan dengan aktivitas di industri asuransi, dana pensiun, lembaga pembiayaan, dan lembaga jasa keuangan lainnya, yang dalam pelaksanaannya tidak bertentangan dengan prinsipprinsip syariah. Secara umum, kegiatannya memang tidak memiliki perbedaan dengan IKNB konvensional. Namun terdapat beberapa karakteristik khusus, dengan produk dan mekanisme transaksi yang berdasarkan prinsip syariah. Di antaranya yang dilakukan Lembaga Keuangan Syariah (LKS) berbasis Hukum Syariah yang difatwakan Dewan Syariah Nasional Majelis Ulama Indonesia (DSN MUI) adalah Pembiayaan Mudharabah (Qiradh), Pembiayaan Musyarakah, Pembiayaan Ijarah, Wakalah, Akad Mudharabah Musytarakah, dan Akad Kafalah. OJK sebagai lembaga pengatur dan pengawas di keuangan syariah juga memiliki fungsi dan kewenangan untuk melakukan integrasi arah kebijakan, strategi, dan tahapan pengembangan di industri keuangan syariah, termasuk di IKNB Syariah. Tentu instrumen regulasi yang dikeluarkan juga sesuai dengan prinsip syariah, dengan melibatkan DSN MUI. (www.ojk.go.id).

Di saat pangsa pasar industri perbankan syariah masih terjebak di bawah lima persen, pangsa pasar industri keuangan non bank (IKNB) syariah telah melampaui lima persen. Berbagai jenis industri di IKNB Syariah seperti asuransi syariah, perusahaan pembiayaan syariah, pegadaian syariah dan pembiayaan ekspor mencatat pangsa pasar di atas lima persen. Desember 2015, total aset Industri Keuangan Non Bank (IKNB) Syariah mencapai Rp 64,8 T. ( http://keuangansyariah.mysharing.co.id).

Aset industri keuangan non bank (IKNB) syariah tumbuh di atas aset IKNB konvensional. Jika aset IKNB konvensional tumbuh 5,55\% maka aset IKNB konvensional tumbuh 7,1\%. Otoritas Jasa Keuangan (OJK) mencatat perkembangan aset IKNB Syariah nilai aset sebesar Rp 62,51 triliun pada November 2015 atau tumbuh 7,1\% dari Rp 58,37 triliun. Aset tiga sektor industri syariah antara lain: asuransi dan reasuransi syariah, lembaga pembiayaan syariah dan lembaga jasa keuangan syariah. Dari dua sektor aset IKNB syariah untuk lembaga jasa keuangan syariah tumbuh 30,5\% menjadi Rp 15,48 triliun pada November 2015. Lalu dari aset asuransi dan reasuransi syariah tumbuh 13,58\% menjadi Rp 25,4 triliun pada November 2015. Terakhir, pada sektor lembaga pembiayaan syariah justru mengalami penurunan 10,4\% menjadi Rp 21,6 triliun pada November 2015 dari Rp 24,15 triliun pada November 2014. (www.kontan.co.id)

Sebagai industri yang tergolong infant, sektor jasa keuangan syariah membutuhkan dukungan riset dan pengembangan sumber daya manusia (SDM) yang andal agar inovasi dan peningkatan daya saingnya dapat dipacu mengejar sektor jasa keuangan lain yang sudah lebih mapan dan dapat mengoptimalkan potensi pertumbuhan, yang akhirnya dapat pula berkontribusi lebih besar bagi pembangunan ekonomi nasional. Mengapa industri jasa keuangan syariah belum bisa secara signifikan berkontribusi dan menggarap sektor-sektor tersebut? Salah satu kunci permasalahan yang selama ini diidentifikasi adalah kurangnya inovasi produk, yang bila dirunut akan bermuara pada perlunya dukungan riset dan kualitas SDM industri keuangan syariah. Dalam rencana strategis pengembangan sektor jasa keuangan syariah, Otoritas Jasa Keuangan (OJK) memiliki banyak agenda untuk mengatasi isu di atas. Salah satu langkah strategis yang dilakukan OJK adalah mendorong tumbuhnya budaya riset dan mendorong minat para akademisi dan peneliti untuk melakukan riset-riset dasar dan terapan dibidang keuangan syariah. (Firdaus Djaelani dikutip dari www.beritasatu.com). 
Otoritas Jasa keuangan (OJK) telah mengeluarkan roadmap IKNB Syariah 2015-2019, bentuk respon terhadap isu-isu strategis dan mencari titik terang dari berbagi isu tersebut. Salah satu isu yang disebutkan dalam roadmap IKNB syariah tentang isu kuantitas dan kualitas sumber daya manusia (SDM). SDM memiliki peran yang sangat penting dalam mendorong perkembangan industry keuangan syariah karena merupakan motor bagi inovasi produk serta peningkatan kualitas proses internal perusahaan dan layanan kepada peserta. Kompetensi sumber daya insane yang diperlukan oleh IKNB syariah tidak terbatas bidang teknis namun termasuk bidang syariah. Kebutuhan akan sumber daya manusia yang memiliki standar kualifikasi yang dilengkapi dengan tingkat kapasitas dan kompetensi yang memadai sangat diperlukan sehingga praktik bisnis syariah dapat menjadi lebih optimal. (Roadmap IKNB Syariah 2015-2019)

Dari uraian diatas maka penulis tertari untuk melakukan penelitian terkait dengan peningkatan kualitas dari sumber daya manusia yang dimiliki oleh Industri Keuangan Non-Bank (IKNB). Penulis memandang dibutuhkan sebuah keonsep yang tepat dalam menghadapi permasalahan kualitas sdm pada IKNB Syariah tersebut. Konsep Calestial Management yang digagas oleh bapak Riawan Amin nampaknya sangat relevan dengan peningkatan kualitas sdm pada IKNB Syariah. Maka dari sini penulis melakukan penelitian yang berjudul urgensi penerapan celestial management bagi peningkatan kualitas sdm pada IKNB syariah.

Permasalahan dalam Penelitian ini adalah: (1) Bagaimana upaya Otoritas Jasa Keuangan (OJK) dalam peningkatan kualitas sumber daya manusia pada IKNB Syariah?; (2) Bagaimana perlukah penerapan celestial management bagi sumber daya manusia pada IKNB syariah?.

Tujuan penulisan ini adalah untuk: (1) Mengetahui tentang upaya Otoritas Jasa Keuangan Syariah (OJK) dalam peningkatan kualitas sumber daya manusia pada IKNB Syariah; (2) Mengetahui tentang perlunya penerapan celestial management bagi sumber daya manusia pada IKNB syariah.

\section{KAJIAN TEORI}

Manajemen Sumber Daya Manusia. Menurut (Ismanto, 2009) Pengertian Manajemen Sumber Daya Insani menurut beberapa ahli diantaranya:

a) Menurut Moses N. Kinggudu, Manajemen Sumber Daya Insani adalah pengembangan pemanfaatan pegawai dalam rangka tercapainya tujuan dan sasaran individu, organisasi, masyarakat, bangsa, dan internasional yang efektif.

b) Menurut Edwin B. Flippo yang dikutip oleh Handoko, Manajemen Sumber Daya Insani adalah perencanaan, pengorganisasian, pengarahan dan pengawasan kegiatankegiatan pengadaan, pengembangan, pemberian kompensasi, pengintegrasian, pemeliharaan dan pelepasan Sumber Daya Insani agar tercapai berbagai tujuan individu, organisasi dan masyarakat.

c) Menurut Marry Parker Follet, Manajemen Sumber Daya Insani diartikan sebagai seni untuk menyelesaikan pegawai/karyawan melalui orang lain.

Tujuan Manajem Sumber Daya Manusia. Menurut (Siagian, 2004) Sedangkan Werther dan Davis menyatakan bahwa tujuan manajemen sumber daya insani itu meliputi beberapa tujuan, antara lain: 
a) Tujuan Kemasyarakatan (Societal objective); Setiap organisasi apapun tujuannya, harus mengingat akibat bagi kepentingan masyarakat umum, di samping itu aspek etika dan atau moral dari produk yang dihasilkan suatu organisasi. Suatu organisasi yang berada di tengah-tengah masyarakat diharapkan membawa manfaat atau keuntungan bagi masyarakat. Oleh sebab itu, semua organisasi mempunyai tanggung jawab mengelola sumber daya insaninya agar tidak mempunyai dampak negative terhadap masyarakat.

b) Tujuan Organisasi (Organization objective); Untuk mengenal bahwa manajemen sumber daya insani itu ada (exist), perlu memberikan kontribusi terhadap pendayagunaan organisasi secara keseluruhan. Manajemen sumber daya insani bukanlah suatu tujuan dan akhir suatu proses, melainkan suatu perangkat atau alat untuk membantu tercapainya suatu tujuan organisasi secara keseluruhan. Oleh sebab itu suatu unit atau bagian manajemen sumber daya insani di suatu organisasi diadakan untuk melayani bagian-bagian lain organisasi tersebut.

c) Tujuan Fungsional (Functional objective); Secara fungsional manajemen sumber daya manusia adalah untuk memelihara (maintain) kontribusi bagian-bagian lain agar mereka (sumber daya manusia dalam tiap bagian) melaksanakan tugasnya secara optimal.

d) Tujuan Pribadi (Personel objective); Kepentingan personal atau individual dalam organisasi juga harus diperhatikan oleh setiap manajer, terutama manajemen sumber daya manusia, dan harus diarahkan dengan tujuan organisasi secara keseluruhan (overall, organizational objectives).

Upaya mendapatkan SDM yang yang berkualitas perlu dilatih dan ditingkatkan kualitasnya agar menjadi manusia yang efektif, efisien, dan produktif. Bagaimana upaya melakukan pelatihan dan pengembangan SDM tersebut ? apa saja pola yang dapat dilakukan ? Di dalam al-qur'an banyak ayat yang mengemukakan teantang ciri khas manusia. Ciri khas manusia tersebut memiliki keistimewaan dan kekuarangan. Manusia memerlukan pelatihan dan pengembangan agar terbentuk individu-individu yang baik yang sanggup memikul amanah dan beban yang diberikan. Bahkan, dengan kekuatan keimanan dan karakter individu yang sabar, dengan izin Allah SWT dapat memenangkan pertempuran. (Veithzal Rifai, 2009).

Konsep Calestial Management. Ajaran agama atau nilai-nilai langit yang dimaksud sebagai pendekatan spiritual dalam praktik bisnis adalah nilai-nilai yang merujuk pada prinsip 3 W, yakni Worship, Wealth, dan Warfare (Riawan Amin, 2006):

A place of Worship (tempat menyembah), artinya tempat bekerja atau bisnis haruslah dimaknai sebagai tempat ibadah. Bekerja adalah bukan untuk mengabdi kepada pimpinan, tetapi bekerja lebih dari itu yaitu mengabdi kepada Allah SWT. Dengan menyadari dan menghayati bahwa manusia adalah hamba Allah, maka sewajarnyalah setiap manusia mengabdikandirinya kepada Allah, dengan mengikuti segala aturan-Nya dan menjauhi segala larangan-Nya. Hal ini sesuai dengan Firman Allah yang berbunyi: " Dan Aku tidak menciptakan jin dan manusia melainkan supaya mereka menyembah-Ku" (QS. AdzDzaariyaat 51:56). Selanjutnya, dikemukakan satu lagi firman Allah yang maksudnya adalah seperti berikut: "Wahai sekalian manusia! Sembahlah Tuhan kamu yang telah menciptakan kamu dan orang-orang yang terdahulu daripada kamu supaya kaтu bertaqwa" (QS. Al-Baqarah:2:21). Rasulullah SAW juga telah bersabda yang artinya: "Orang yang mencari penghidupan itu adalah kawan Tuhan" (HR.Al-Bukhari). 
Ada perbedaan ketika bekerja untuk kerja (mencari nafkah) dan bekerja untuk ibadah. Bekerja untuk kerja (hanya mencari nafkah) akan cenderung menghalalkan segala cara untuk memperoleh hasil yang sebanyak-banyaknya. Sedangkan bekerja untuk ibadah melihat hasil yang baik hanya diperoleh dengan niat, tujuan, dan cara yang baik, yaitu dengan niat, tujuan, dan cara-cara yang dibenarkan oleh Allah SWT. Kalau hal ini diikuti, maka kemungkinan hasil yang diperoleh tidak begitu banyak tetapi ada nilai berkah di dalamnya. Oleh sebab itu, nilai-nilai Worship diturunkan dalam konsep ZIKRyaitu Zero Base, Iman, Konsisten, ResultOriented.

ZeroBase. Zero base artinya pekerjaan, usaha atau bisnis haruslah dimulai dari hati atau niat yang bersih, tulus, dan suci, sehingga menerima dengan lapang dada apa yang diberi, tidak pernah menawar-nawar terhadap pemberian. Bersih dari paradigma yaitu tidak terbelenggu oleh masa lalu, tidak selalu terpancang apa yang dikerjakan di masa lalu, tetapi apa yang dihadapi pada saat sekarang ini (Riawan Amin, 2006).

Hal ini sejalan dengan Ary Ginanjar Agustin (2006) bahwa tahap awal untuk membangun kecerdasan emosi dan spiritual adalah melalui penjernihan emosi (zero mind process) diantaranya dengan menjauhkan diri dari prasangka. Hindari untuk selalu berprasangka buruk, dan usahakan untuk berprasangkabaik. Allah SWT berfirman "Katakanlah, jika kamu menyembunyikan apa yang ada dalam hatimu atau kamu menampakkannya, pasti Allah mengetahuinya" (QS. Ali Imran 3:29). Selanjutnya, Rasulullah SAW juga bersabda "Setiap amal disertai dengan niat. Setiap amal seseorang tergantung dengan apa yang diniatkannya. Karena itu, siapa saja yang hijrahnya karena Allah dan Rasul-Nya, maka hijrahnya tertuju kepada Allah dan Rasul-Nya. Tetapi siapa saja yang melakukan hijrah demi kepentingan dunia yang akan diperolehnya, atau karena perempuan yang akan dinikahinya, maka hijrahnya sebatas kepada sesuatu yang menjadi tujuannya" (HR. Bukhari dan Muslim).

Iman. Iman artinya suatu keyakinan akan kekuasaan Allah SWT, keyakinan akan janjijanji Allah SWT. Zero base tidak akan ada artinya apabila tidak diisi dengan iman. Setelah dimulai dari hati yang bersih lalu dilakukan dengan penuh keyakinan, dan selalu optimis, maka pada akhirnya iman (penuh keyakinan) tersebut dapat menghilangkan rasa takut dan cemas. Penuh keyakinan dapat merubah sesuatu yang tak mungkin menjadi mungkin (impossible to be possible). Jadi dalam bekerja atau melakukan bisnis harus disertai dengan suatu keyakinan terhadap diri sendiri bahwa diri ini mampu mengatasi masalah, mampu meraih prestasi dan sebagainya, karena Allah SWT sudah berjanji dalamfirmanfirmanNya.

"Dan tatkala orang-orang muslim melihat golongan-golongan yang bersekutu itu, mereka berkata: "Inilah yang dijanjikan Allah dan Rasul- Nya kepada kita." Dan benarlah Allah dan Rasul-Nya. Dan yang demikian itu tidaklah menambah kepada mereka kecuali iman dan ketundukan" (QS. Al-Ahzab 33:22). Selanjutnya, Rasulullah SAW bersabda "Andaikata kalian benar-benar bertawakkal kepada Allah niscaya Allah akan memberi kalian rezeki sebagaimana Dia memberi rezeki kepada burung, yaitu keluar dengan perut kosong di pagi hari dan kembali dengan perut kenyang di sore hari" (HR.Tirmidzi). Konsisten (Istiqomah dankaffah).

Konsisten. Maksudnya untuk sampai pada titik sasaran, zero base dan iman harus dijaga secara konsisten/harus istiqomah dan kaffah. Banyak orang bisa membuat rencana dengan baik, tetapi ketika mengimplementasikannya tidak konsisten dalam mengarahkan kepada 
suatu tujuan yang telah ditetapkan, akibatnya keselarasan yang diharapkan tidak muncul/tidak tercipta, justru yang muncul kebimbangan oleh berbagai tarikan dan motif yang berbeda. Agar selalu konsisten, diri ini perlu hati-hati dalam memfokuskan usaha atau bisnis demi tercapainya sasaran. Jadi dalam melakukan suatu pekerjaan atau bisnis harus selalu konsisten, baik dalam niat, motivasi maupuntujuan.

Allah SWT berfirman "Dan tetaplah sebagaimana diperintahkan kepadamu" (QS. Asy-Syuura 42:15). Selanjutnya, Rasulullah SAW juga bersabda "Biasakanlah kalian dalam mendekatkan diri kepada Allah dan berpegang teguhlah pada keyakinan kalian. Ketahuilah!, tidak ada seorangpun di antara kalian yang selamat karena amal perbuatannya." Para sahabat bertanya: "Tidak juga engkau wahai Rasulullah?" Beliau menjawab: "Tidak juga saya, kecuali jika Allah melimpahkan rahmat dan karunia-Nya" (HR. Muslim).

ResultOriented. Result oriented, dapat diartikan bahwa dalam bekerja atau bisnis sebagai suatu perwujudan ibadah, maka harus mempunyai Result Oriented. Result Oriented yang dimaksud disini adalah Mardhatillah/Willing Of God (keridhaan Allah SWT). Jadi tujuan bekerja atau bisnis bukan semata-mata untuk memperoleh materi, tahta, gengsi, popularitas, tetapi result oriented yang harus dimiliki adalah keridhaan Allah SWT (The UltimateResult).

Allah SWT berfirman "Daging-daging unta dan darahnya itu sekali- sekali tidak dapat mencapai (keridhaan) Allah, tetapi ketakwaanmulah yang dapat mencapainya" (QS. Al-Hajj 22:37). Selanjutnya, Rasulullah SAW bersabda "Siapa saja yang berperang agar kalimat Allah terangkat, maka itulah perang di jalan Allah" (HR. Bukhari dan Muslim).

Dengan memahami maksud ayat-ayat Al-Quran dan hadist di atas dan menyadari bahwa bekerja itu berarti ibadah, maka sewajarnyalah bagi setiap pekerja berusaha menunaikan tugasnya dengan sebaik-baiknya demi kebahagiaan hidup di dunia dan akhirat kelak. Dengan demikian, keempat atribut di atas (ZIKR) adalah saling berkaitan, dari niat yang bersih, diisi dengan iman, dilakukan secara konsisten untuk mencapai tujuan yang pasti, yaitu Mardhatillah. Konsep ZIKR yang dipahami dan diterapkan oleh seseorang akan menempatkannya sebagai individu yang berpotensi unggul. Empat atribut tersebut menjadi modal dasar dalam mengelola kegiatan bisnis dan pekerjaan untuk menghasilkan yangterbaik.

A Place of Wealth (tempat kesejahteraan)Artinya tempat bekerja atau bisnis haruslah dijadikan sebagai pusat dari berkumpul dan dibaginya kesejahteraan dengan adil. Kesejahteraan yang seimbang antara material dan immaterial. Penyelesaian tugas akan tergantung pada banyak faktor. Pembagian tugas itu harus jelas, sehingga apapun yang berkaitan dengan kesuksesan/kelancaran bekerja harus dibagi/sharing denganadil.

Allah SWT berfirman "Sesungguhnya Allah menyuruh (kamu) berlaku adil dan berbuat kebajikan" (QS. An-Nahl 16:90). Selanjutnya Rasulullah SAW bersabda "Sesungguhnya orang-orang yang berlaku adil di sisi Allah laksana berada di atas mimbar yang terbuat dari cahaya. Mereka itu orang- orang yang berlaku adil dalam memberikan hukum kepada keluarga dan rakyat yang mereka kuasai (perintah)" (HR. Muslim).

Sedangkan dalam manajemen ini ada empat atribut utama, yang terangkum dalam akronim P I K R(Power, Information, Knowledge, dan Reward). 
a) Power Sharing (Pembagiankekuasaan). Pembagian kekuasaan/pendelegasiaan kekuasaan dapat diartikan bahwa seorang individu tidak bisa sendirian dalam bekerja tetapi haruslah berkelompok, bersama-sama dengan pegawai/karyawan lainnya, duduk bersama dalam sebuah team. Sehingga bagus tidaknya pekerjaan team, tidak lagi ditentukan oleh keunggulan satu/dua orang saja, tetapi oleh kekompakan mereka dalam menjalankan fungsinya masing-masing. Jadi dalam lingkungan kerja, harus dipahami peran masing-masing dan sesuai dengan jabatan masing-masing. Setiap individu harus kembali merenung siapa dirinya, sebagai apa, tugas apa yang menjadi bagiannya. Bila sebagai pimpinan apakah sudah ada power sharing/pembagian kewenangan sehingga dalam pengambilan keputusan tidak bertele-tele harus sampai pada pucuk pimpinan. Bila sebagai penerima delegasi harus dilaksanakan dengan penuh tanggung jawab.

Allah SWT berfirman "Tolong menolonglah kamu sekalian dalam kebaikan dan taqwa" (QS. Al-Maidah 5:2). Selanjutnya, Rasulullah SAW bersabda "Hendaknya tiap dua orang dalam satu keluarga, yang satu keluar dan yang lain menjaga keluarga-keluarganya yang ditinggal, niscaya pahalanya terbagi antara keduanya sama" (HR. Muslim).

b) Information Sharing (pembagininformasi)

Dalam melaksanakan tugas sebagai penerima pendelegasian (power sharing), ditentukan oleh terbaginya informasinya yang diperoleh. Jika individu bertugas di unit terbawah tentunya banyak informasinya dari atas, maka baik tidaknya/lancar tidaknya pekerjaannya juga ditentukan oleh pembagian informasinya. Bila informasi yang disampaikan tidak lengkap tentu penyelesaian pekerjaan tidak sempurna. Umpamanya informasi tentang teori, style atau skill untuk menyelesaikan pekerjaan.

Allah SWT berfirman "M aka sampaikanlah secara terang-terangan segala sesuatu yang diperintahkan (kepadamu)" (QS.Al-Hijr 15:94). Selanjutnya, Rasulullah SAW bersabda "Siapa saja yang menunjukkan (mengajak) kepada kebaikan, maka ia mendapat pahala seperti pahala orang yang mengerjakan kebaikan itu" (HR. Muslim).

c) Knowledge Sharing (pembagianpengetahuan)

Pembagian informasi yang diperlukan akan sia-sia bila tidak terjadi knowledge sharing (pembagian pengetahuan dan keterampilan), sehingga yang mengetahui teknik-teknik permainan hanya itu-itu saja, akibatnya sebagian pegawai/karyawan tidak cukup pengetahuan dalam melaksanakan tugas. Dalam kaitannya dengan tugas, tidak hanya pimpinan saja yang mendapat pengetahuan, tidak hanya yang mendapat pelatihan saja yang mengetahui ilmu-ilmu tertentu, tetapi harus dibagi kepada semua yang terkait, dengan cara ditularkan dan ditransfer kepada yang tidak mendapat pelatihan, atau yang tidak mempunyaipengetahuan.

Allah SWT berfirman "Demi masa. Sesungguhnya manusia itu benar - benar rugi, kecuali orang-orang yang beriman dan mengerjakan amal saleh dan nasihat menasihati supaya mentaati kebenaran dan nasihat menasihati supaya menetapi kesabaran" (QS. Al-Ashr 103:1-3). Selanjutnya, Rasulullah SAW bersabda "Siapa saja yang menyediakan perbekalan perang di jalan Allah, maka ia disamakan dengan perang, dan siapa saja yang tidak ikut perang lalu menjaga baik-baik keluarga yang ditinggalkan orang yang ikut perang, berarti ia ikut perang" (HR. Bukhari danMuslim). 
d) Reward Sharing (pembagianhadiah/ganjaran)

Setelah kekuasaan dibagi/didelegasian, informasi diperoleh, pengetahuan dan skill dikuasai, tinggal satu hal yang perlu diperoleh, yaitu naluri untuk menjadi pekerja atau karyawan yang sukses, seperti dalam permainan sepak bola naluri mencetak gol. Pemain akan berlomba-lomba mencetak gol bila ia cukup terangsang dengan imbalan yang akan diterima. Imbalan untuk pemain/pekerja itulah yang disebut Reward. Reward tidak selalu berbentuk uang, tetapi juga penghargaan, sekurangkurangnya pengakuan dari atasan. Jadi reward diterima terakhir, setelah adaprestasi.

Allah SWT berfirman "Dan kebaikan apa saja yang kamu perbuat untuk dirimu niscaya kamu memperoleh balasannya di sisi Allah sebagai balasan yang paling baik dan yang paling besar pahalanya" (QS. Al- Muzzammil 73:20). Selanjutnya, Rasulullah SAW bersabda "Apabila seseorang mendekatkan diri kepada Allah sejengkal, maka Allah mendekat sehasta, apabila ia mendekatkan diri kepada Allah sehasta, maka Allah mendekat sedepa, dan apabila ia datang kepada Allah dengan berjalan maka Allah datang dengan berlari" (HR. Bukhari).

Orang/pejabat yang mempunyai kekuasaan untuk memberikan reward harus memperhatikan prestasi pegawainya/bawahan sehingga reward betul-betul akan terbagi sesuai dengan presatasi masing-masing. Jadi prestasi dulu yang diwujudkan, baru ada reward, bukan sebaliknya reward dipersoalkan dulu, baru prestasi. Disamping reward positive ada juga reward negative. Sudah sewajarnya bila setiap prestasi mendapat apresiasi, demikian pula bila terjadi sebaliknya, manajemen seharusnya memberikan reward negative atau hukuman (punishment).

Dalam pemberian punishment ada satu sikap yang menjadi pedoman. Kalau memang ditemukan kesalahan, sanksi harus dijatuhkan, tidak perlu kemudian diringan-ringankan dan ada pertimbangan pribadi sehingga keputusan menjadi tidak obyektif.

A Place of Warfare (tempat pertempuran). Misalnya dalam dunia penegakan hukum, peradilan harus mampu menjadi medan pertempuran dalam mewujudkan keadilan, bukanlah Islam hadir justru untuk menegakkan keadilan bukan untuk merobohkannya? Dalam dunia bisnis juga harus mampu menjadi medan pertempuran dalam memajukan ekonomi umat/rakyat. Untuk menjadi the dream team disegala medan pertempuran, setiap karyawan/pergawai harus membekali diri dengan atribut M I K R(Militan, Intelek, Kompetitif,Regeneratif).

a) Militan. Dalam pekerjaan atau bisnis, kita tentunya dihadapkan dengan pertempuran, persaingan/kompetisi dalam bekerja, kita akan memilih sesuatu untuk menjadi pemenang dalam persaingan. Pilihan yang sulit tidak mungkin lahir dari individu yang pengecut, bukan pribadi yang loyo, tetapi pribadi yang mempunyai semangat yang tinggi dan teguh pendirian dalam mengerjakanya, itulah yang disebutMilitan.

Allah SWT berfirman "Maka istiqomahlah (tetaplah teguh pendirian) kamu pada jalan benar sebagaimana diperintahkan kepadamu dan juga orang yang telah bertaubat bersama kamu" (QS. Huud 11:112). Selanjutnya, Rasulullah SAW bersabda "Katakanlah, saya beriman kepada Allah, kemudian teguhlah kamu dalam pendirian itu" (HR. Muslim). 
Militan artinya "bersemangat tinggi", 'penuh gairah' (kamus besar bahasa Indonesia). Dia siap untuk memberikan hasil yang baik serta semangat untuk berjuang, dan dia hadir untuk menjadi pemenang bukan pecundang.Kelompok militan mempunyai fungsi secara maksimal, mereka adalah pribadi yang pintar itu menggunakan pikirannya untuk mencari sebuah solusi dari problem-problem yang ada di samping mereka.

b) Intelek. Intelek adalah kemampuan untuk menggunakan pikirannya dalam mencari sebuah solusi dari masalah-masalah yang ada. Orang intelek akan menggunakan semua knowledge dan skill yang membutuhkan untuk berprestasi. Ia akan memaksimalkan attitude positif untuk mendorong kebutuhan untuk memajukan diri dan lembaga tempatnya berkiprah.

Allah SWT berfirman "Maka bertanyalah kepada orang yang mempunyai pengetahuan jika kamu tidak mengetahui" (QS. An-Nahl 26:43). Selanjutnya, Rasulullah SAW bersabda "Dan apa yang aku perintahkan kepada kalian, maka laksanakan semampu kalian" (HR. Al- Bukhari dan Muslim).

Kelompok intelektual yang dibuat di dalam fondasi yang militan akan melahirkan para pejuang yang siap untuk memberikan keterampilan yang terbaik. Dalam kata lain militan akan memberikan hasil atau kemampuan yang terbaik.

\section{c) Kompetitif}

Kompetitif adalah mereka yang tidak saja memiliki penguasaan knowledge dan informasi yang dibutuhkan untuk berprestasi, tetapi juga mereka yang mempunyai kemauan untuk berperan serta menyumbangkan kinerja terbaiknya buat organisasinya.Allah SWT berfirman "M aka berlomba-lombalah kamu dalam berbuat kebaikan" (QS. Al-Baqarah 2:148, Al-Maidah 5:51). Selanjutnya, Rasulullah SAW bersabda "Seorang muslim yang menjadi bendahara, adalah orang yang dapat dipercaya. Ia melaksanakan tugas yang dilimpahkan dengan sempurna dan senang hati, serta memberikan sesuatu kepada siapa yang diperintahkan, maka ia termasuk salah sorang yang mendapat pahala bersedekah" (HR. Bukhari dan Muslim).

\section{d) Regeneratif}

Regeneratif artinya kemampuan kompetitif atau kesuksesan yang didapatkan dan harus bisa dijaga terus-menerus serta diwariskan kepada generasi berikutnya. Generasi yang cakap adalah generasi yang dilahirkan dan dibangun serta bisa membangkitkan pemimpin yang kompetitif yang mempunyai waktu yang panjang. Maksud dari kalimat di atas bahwa kesuksesan itu tidak hanya dicapai dalam satu periode, tetapi membutuhkan periode berikutnya/generasi penerus. Kunciya terletak pada kesadaran dan kesabaran dari setiap karyawan/pegawai untuk terus ZIKR dan SharingPIKR.

Allah SWT berfirman " D an sesungguhnya Kami benar-benar akan menguji kamu agar Kami mengetahui orang-orang yang berjihad dan bersabar di antara kamu" (QS. Muhammad 47:31). Selanjutnya, Rasulullah SAW bersabda "Semua kebaikan yang ada padaku tidak akan aku sembunyikan pada kalian. Siapa saja yang menjaga kehormatan dirinya, maka Allah pun akan menjaganya dan siapa saja yang merasa cukup, maka Allah akan mencukupinya. Serta siapa saja yang menyabarkannya dirinya, maka Allah pun akan memberi kesabaran. Dan seseorang tidak akan mendapatkan anugerah yang lebih baik atau lebih lapang melebihi kesabaran" HR. Bukhari danMuslim). 
Dari uraian di atas dapat disimpulkan bahwa dalam melakukan praktik bisnis bisa mencapai kesuksesan, apabila para pemimpin dan karyawannya dapat menerapkan nilai-nilai langit (celestial value/celestial management) yang telah dijelaskan di atas sebagai pendekatan spiritual manajemennya di dalam kegiatan operasional seharihari.

\section{METODE}

Jenis Penelitian. Jenis penelitian yang digunakan dalam tulisan ini adalah dengan menggunakan liberary riset atau studi pustaka yang diperoleh dari beberapa sumber, yang dianggap mendukung tema yang diangkat dari tulisan ini.

Sifat Penelitian. Penelitian ini bersifat deskriptif kualitatif yang artinya menggambarkan suatu subyek penelitian. Dalam hal ini adalah bentuk kondisi sumber daya manusia di bank syari'ah. Kemudian tentang perlunya penerapan Celestial Management bagi sumber daya manusia pada IKNB syari'ah.

Jenis Data. Jenis data yang digunakan dalam tulisan ini adalah data kualitatif yang bersumber dari data primer dan data sekunder. Data primer berupa sumber data yang langsung memberikan data kepada peneliti atau data yang diperoleh secara langsung, sedangkan data sekunder adalah sumber data yang tidak langsung memberikan data kepada pengumpul data (peneliti) atau data yang diambil peneliti sebagai pendukung atas penelitian secara ilmiah yaitu dengan melakukan studi pustaka (penelusuran melalui buku, artikel, jurnal, majalah, internet dan sumber lainnya).

Data-data yang digunakan penulis antara lain: (1) teori-teori yang peneliti ambil dari berbagai literatur; (2) Pengambilan data-data dari hasil yang telah tersaji dari suatu lembaga.

Batasan Penelitian. Batasan dalam tulisan ini difokuskan pada kondisi sumber daya manusia pada IKNB syariah. Batasan dalam tulisan ini juga pada kondisi factual tentang keberadaan kondisi sumber daya manusia pada IKNB syariah, kemudian perlunya penerapan celestial management bagi sumber daya manusia pada IKNB syariah.

Teknik Pengumpulan data. Teknik pengumpulan data yang diperlukan dalam tulisan ini adalah dengan menggunakan beberapa metode yaitu: (1) Studi Kepustakaan. Metode ini digunakan untuk menggali dasar-dasar teori yang terkait dengan pengembangan sumber daya manusia pada IKNB syariah dan konsep dari celestial management; (2) Pengamatan. Setiap data yang didapatkan dari berbagai sumber diamati dan dianalisa terkait dengan kondisi sumber daya manusia pada IKNB syariah.

Analisis Data. Metode analisis data yang digunakan adalah dengan menggunakan pendekatan kualitatif deskriptif yaitu dengan cara memaparkan metode teori terkait sumber daya manusia, serta perlunya penerapan celestial management pada IKNB syariah. Kemudian bagaimana konsep celestial management penerapannya bagi sumber daya manusia pada IKNB Syariah, sebagai bentuk menciptakan sumber daya manusia yang berkualitas. 
Penelitian kualitatif adalah prosedur penelitian yang menghasilkan data deskriptif berupa kata-kata tertulis atau lisan dari orang-orang dan keadaan yang diamati. Penelitian kualitatif adalah metode penelitian yang digunakan untuk meneliti pada kondisi objek yang alamiah, (sebagai lawannya adalah eksprimen) dimana peneliti adalah sebagai instrument kunci, teknik pengumpulan data dilakukan secara trianggulasi (gabungan), analisa data bersifat induktif dan hasil dari penelitian kualitatif lebih bersifat makna daripada generalisasi.

\section{HASIL DAN PEMBAHASAN}

\section{Upaya peningkatan kualitas Sumber Daya Manusia pada IKNB Syariah}

Tabel 1. Meningkatkan Dukungan SDM IKNB Syariah 2015-2019

\begin{tabular}{|c|c|c|c|c|c|}
\hline \multirow[t]{2}{*}{ Strategi \& Rencana Aksi } & \multicolumn{5}{|c|}{ Waktu Pelaksanaan } \\
\hline & 2015 & 2016 & 2017 & 2018 & 2019 \\
\hline \multicolumn{6}{|c|}{$\begin{array}{l}\text { Strategi } 1 \\
\text { Menerapkan ketentuan sertifikasi standar profesi para pelaku IKNB Syariah secara bertahadap untuk } \\
\text { Direksi, Komisaris, Tenaga Ahli, dan Dewan Pengawas Syariah }\end{array}$} \\
\hline \multicolumn{6}{|c|}{ Rencana Aksi: } \\
\hline $\begin{array}{l}\text { 1) Menyusun standar } \\
\text { kompetensi untuk Dewan } \\
\text { Pengawas Syariah. }\end{array}$ & $*$ & $\%$ & $*$ & $*$ & $*$ \\
\hline $\begin{array}{l}\text { 2) Mendorong sertifikasi } \\
\text { bagi manajemen dan } \\
\text { Dewan Pengawas Syariah } \\
\text { di IKNB Syariah. }\end{array}$ & $\checkmark$ & $\checkmark$ & $\checkmark$ & $\checkmark$ & $\checkmark$ \\
\hline 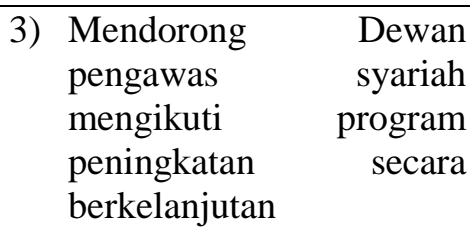 & & $*$ & $\$$ & $\%$ & 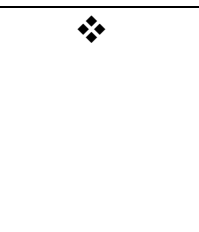 \\
\hline
\end{tabular}

Sumber: OJK (Roadmap IKNB Syariah 2015-2019

Tabel 2. Meningkatkan Dukungan SDM IKNB Syariah 2015-2019

\begin{tabular}{|l|l|l|l|l|c|}
\hline \multirow{2}{*}{ Strategi \& Rencana Aksi } & \multicolumn{4}{|l|}{ Waktu Pelaksanaan } & \multicolumn{2}{l|}{} \\
\cline { 2 - 6 } & 2015 & 2016 & 2017 & 2018 & 2019 \\
\hline $\begin{array}{l}\text { Strategi II } \\
\text { Mendukung kerjasama IKNB Syariah dengan instansi dan pihak terkait untuk melahirkan lebih } \\
\text { banyak sumber daya manusia profesional di bidang IKNB Syariah. }\end{array}$ \\
\hline Rencana Aksi: & & & & \\
\hline $\begin{array}{l}\text { 1) Mendorong pendirian } \\
\text { lembaga standar profesi di } \\
\text { bidang IKNB Syariah. }\end{array}$ & $\sqrt{ }$ & & & \\
\hline
\end{tabular}




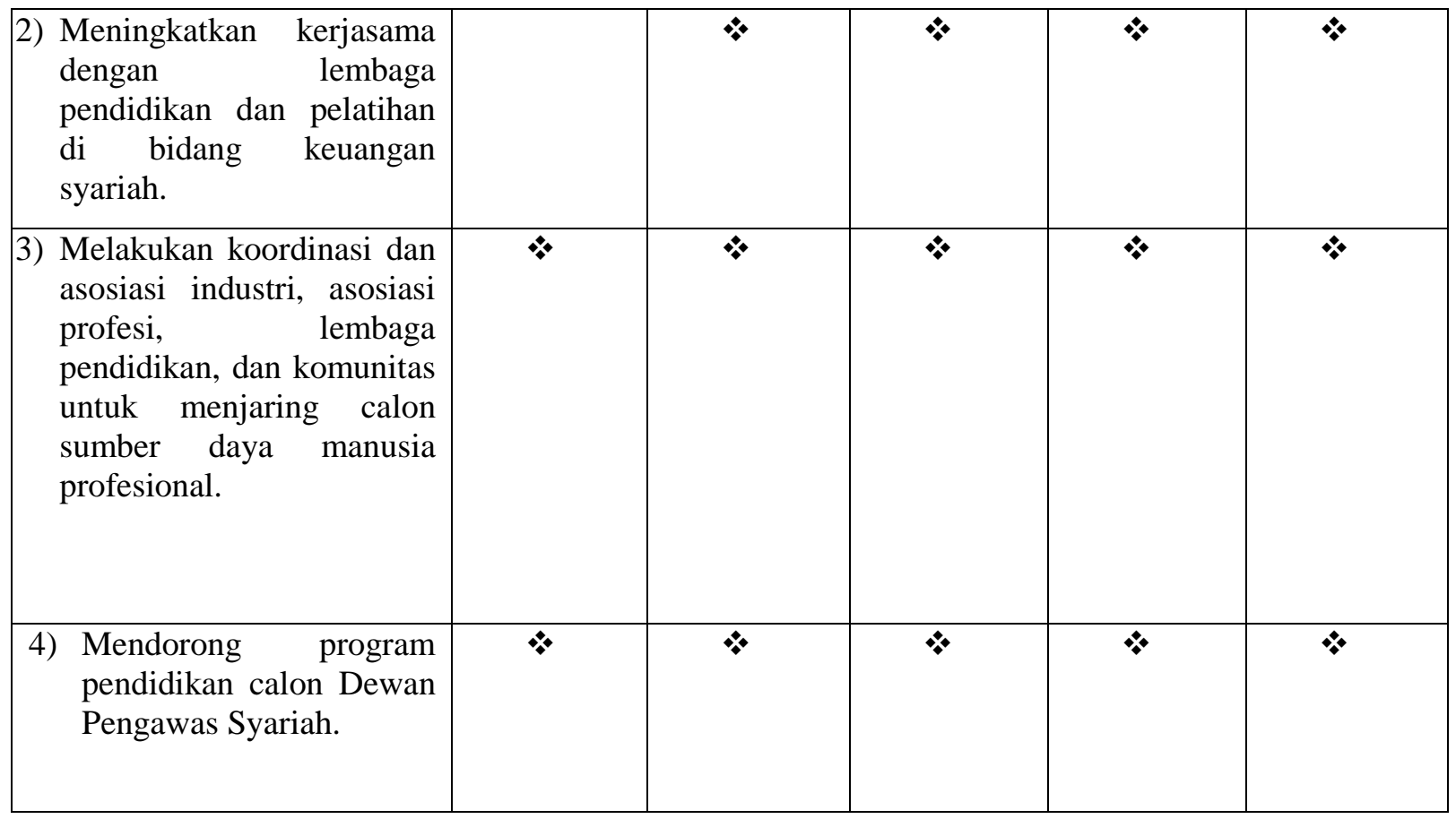

Sumber: OJK (Roadmap IKNB Syariah 2015-2019

\section{Keterangan:}

\section{$\checkmark \quad$ Rencana aksi utama \\ * Rencana aksi}

Dari kedua tabel diatas menunjukkan adanya upaya OJK dalam meningkatkan kualitas dari sumber daya manusia pada IKNB Syariah untuk lebih baik kedepannya. Upaya tersebut memiliki dua strategi yang pertama, Menerapkan ketentuan sertifikasi standar profesi para pelaku IKNB Syariah secara bertahadap untuk Direksi, Komisaris, Tenaga Ahli, dan Dewan Pengawas Syariah. Kedua, Mendukung kerjasama IKNB Syariah dengan instansi dan pihak terkait untuk melahirkan lebih banyak sumber daya manusia profesional di bidang IKNB Syariah. Hanya saja kurang terlihat optimis karena yang menjadi aksi utama hanya terletak pada satu poin yaitu Mendorong sertifikasi bagi manajemen dan Dewan Pengawas Syariah di IKNB Syariah. Padahal semua aksi membutuhkan perhatian yang lebih dalam meningkatkan kualitas sumber daya manusia pada IKNB Syariah.

Urgensi Calestial Management Bagi SDM pada IKNB Syariah. Konsep Celestial Management memiliki tiga unsur penting yaitu ZIKR, PIKR, MIKR

ZIKR, yang terdiri dari (Zero Base, Iman, Konsisten, dan Result Oriented). Zero menunjukkan bahwa erat kaitannya dengan niat, ketulusan dalam bekerja. Sumber daya manusia pada IKNB syariah harus meniatkan agar setiap yang dilakukannya bertujuan mencari ridha dari Allah SWT, agar tidak sia-sia dan mendapatkan rahmatNya. Dengan demikian sumber daya manusia pada IKNB syariah akan memacu diri dalam bekerja.

Iman menunjukkan erat kaitannya suatu keyakinan akan kekuasaan Allah SWT, keyakinan akan janji-janji Allah SWT. Sumber daya manusia pada IKMB syariah harus 
memiliki iman keyakian bahwa apa yang dilakukannya selalu dalam pantauan dari Allah SWT, sehingga mereka merasa enggan dalam berbuat hal-hal yang dilarang.

Konsisten, maksudnya untuk sampai pada titik sasaran, zero base dan iman harus dijaga secara konsisten/harus istiqomah dan kaffah. Sumber daya manusia pada IKNB syariah harus konsisten dalam menjalankan tugasnya sebagai sumber daya manusia di bank syariah. Konsisten jika mempertahankan prestasi yang telah dimiliki, dan terus konsisten membenahi setiap kekurangan di lingkungan kerja IKNB syariah. Konsisten dalam mengembangkan produk dan inovasi di bank syariah, serta memasarkan perbankan syariah kepada seluruh lapisan masyarakat.

Result oriented, dapat diartikan bahwa dalam bekerja atau bisnis sebagai suatu perwujudan ibadah, maka harus mempunyai Result Oriented. Result Oriented yang dimaksud disini adalah Mardhatillah/Willing of God (keridhaan Allah SWT). Yaitu orientasi utama menjadi sumber daya manusia pada IKNB syariah yaitu mengetahui orientasi yaitu falah bahagia di dunia dan akhirat. Meskipun IKNB syariah itu adalah lembaga bisnis, tapi tidak mengabaikan hal-hal yang bisa melanggar aturan agama. Orientasi dunia dan akhirat harus dimiliki oleh sumber daya manusia pada IKNB syariah, karena menjadi pembeda dengan orientasi bank konvensional.

\section{P I K R (Power, Information, Knowledge, dan Reward). Power Sharing} (Pembagiankekuasaan), Pembagian kekuasaan/pendelegasiaan kekuasaan dapat diartikan bahwa seorang individu tidak bisa sendirian dalam bekerja tetapi haruslah berkelompok, bersama-sama dengan pegawai/karyawan lainnya, duduk bersama dalam sebuah team. Hal ini menunjukkan bahwa sumber daya manusia pada IKNB syariah harus memiliki sifat power sharing dalam bekerja, sebagai bentuk profesionalisme, bahwa setiap mereka memiliki amanah, yang harus dipertanggungjawabkan. Dengan demikian ada kebersamaan antara sumber daya manusia.

Information, Dalam melaksanakan tugas sebagai penerima pendelegasian (power sharing), ditentukan oleh terbaginya informasinya yang diperoleh. Jika individu bertugas di unit terbawah tentunya banyak informasinya dari atas. Sumber daya manusia pada IKNB syariah, harus pekah dan memiliki akses informasi yang baik. Dalam rangka bisa meningkatkan skill, memicu inovasi dalam menciptakan produk, serta strategi dalam menjaring nasabah yang lebih banyak. Dengan informasi ini sumber daya manusia pada IKNB syariah tidak akan ketinggalan dalam mengembangkan diri.

Knowledge Sharing (pembagianpengetahuan), Pembagian informasi yang diperlukan akan sia-sia bila tidak terjadi knowledge sharing (pembagian pengetahuan dan keterampilan), sehingga yang mengetahui teknik-teknik permainan hanya itu-itu saja, akibatnya sebagian pegawai/karyawan tidak cukup pengetahuan dalam melaksanakan tugas. Knowledge Sharing harus dimiliki oleh sumber daya manusia pada IKNB syariah, mengingat IKNB syariah punya perbedaan yang sangat signifikan dengan bank konvensional, sehingga sumber daya manusia pada IKNB syariah dituntut memiliki knowledge yang lebih jika di banding bank konvensional. Mana mungkin sumber daya manusia pada IKNB syariah bisa memasarkan atau menjelaskan jika tidak memiliki knowledge tentang IKNB syariah. 
Reward Sharing (pembagianhadiah/ganjaran), Imbalan untuk pemain/pekerja itulah yang disebut Reward. Reward tidak selalu berbentuk uang, tetapi juga penghargaan, sekurang- kurangnya pengakuan dari atasan. Jadi reward diterima terakhir, setelah adaprestasi. Sebagai sumber daya manusia yang bekerja pada IKNB syariah harus dituntut berbuat adil, khususnya bagi pimpinan bank syariah. Harus berlaku professional terhadap karyawan yang dimilikinya, ketika ada karyawan yang berprstasi sebaiknya diberikan reward hadiah, begitupun jika ada karyawan yang berbuat salah sebaiknya diberi ganjaran.

M I K R (Militan, Intelek, Kompetitif,Regeneratif). Militan, Pilihan yang sulit tidak mungkin lahir dari individu yang pengecut, bukan pribadi yang loyo, tetapi pribadi yang mempunyai semangat yang tinggi dan teguh pendirian dalam mengerjakanya, itulah yang disebutMilitan. Sumber daya manusia pada IKNB syariah harus berjiwa militant, tidak mudah menyerah dan putus asa. Mengingat bank syariah sedang mengalami proses perkembangan sehingga dibutuhkan kesungguhan dari para sumber daya manusianya untuk bekerja dengan penuh semangat agar IKNB syariah bisa bersaing dengan bank konvensional dalam merebut pasar.

Intelek, adalah kemampuan untuk menggunakan pikirannya dalam mencari sebuah solusi dari masalah-masalah yang ada. Orang intelek akan menggunakan semua knowledge dan skill yang membutuhkan untuk berprestasi. Sumber daya manusia pada IKNB syariah sangat dituntut untuk bisa berfikir cerdas (intelek), mampu membaca setiap peluang yang ada, kemudian dituntut untuk bisa lebih banyak menciptakan inovasi produk IKNB syariah. Mampu menciptakan produk yang bernilai ekonomi dan dan berjalan sesuai dengan prinsip syariah. Mampu melihat kebutuhan apa saja yang dicari para konsumen, sehingga dengan intelektualitas sumber daya manusia akan terus memajukan IKNB syariah.

Kompetitif adalah mereka yang tidak saja memiliki penguasaan knowledge dan informasi yang dibutuhkan untuk berprestasi, tetapi juga mereka yang mempunyai kemauan untuk berperan serta menyumbangkan kinerja terbaiknya buat organisasinya. Kompetisi antara IKNB syariah akan terus berjalan, khusunya dalam menarik nasabah, siapa yang memiliki jiwa kompetisi yang baik maka dia yang akan mendapatkan pasar. Sumber daya manusia pada IKNB syariah harus selalu siap dalam menjalani kompetisi, dengan IKNB konvensional. Sumber daya manusia harus kompetitif dalam menjalankan bisnisnya.

Regeneratif artinya kemampuan kompetitif atau kesuksesan yang didapatkan dan harus bisa dijaga terus-menerus serta diwariskan kepada generasi berikutnya. Generasi yang cakap adalah generasi yang dilahirkan dan dibangun serta bisa membangkitkan pemimpin yang kompetitif yang mempunyai waktu yang panjang. Sumber daya manusia pada IKNB syariah harus memiliki sifat regeratif, artinya para senior yang banyak memiliki ilmu dan pengalaman mau membagi kepada juniornya. Tidak pelit sharing dengan juniornya yang sedang proses pengembangan diri. Mewariskan yang baik dan meninggalkan yang buruk, dengan demikian IKNB syariah akan selalu memiliki sumber daya manusia yang unggul. 


\section{PENUTUP}

Pertama. Upaya yang dilakukan Otoritas Jasa Keuangan dalam peningkatan kualitas sumber daya manusia pada IKNB Syariah tertuang dalam dua strategi. Pertama, Menerapkan ketentuan sertifikasi standar profesi para pelaku IKNB Syariah secara bertahadap untuk Direksi, Komisaris, Tenaga Ahli, dan Dewan Pengawas Syariah. Kedua, Mendukung kerjasama IKNB Syariah dengan instansi dan pihak terkait untuk melahirkan lebih banyak sumber daya manusia profesional di bidang IKNB Syariah.

Kedua. Konsep celestial management terdiri dari ZIKR ( Zero Base, Iman, Konsisten, dan Result Oriented), kemudian PIKR (P I K R (Power, Information, Knowledge, dan Reward), dan MIKR (Militan, Intelek, Kompetitif,Regeneratif). Unsur-unsur ini menjadi penting dan sangat perlu diterapkan bagi sumber daya manusia pada IKNB Syariah. Hal ini mampu mengimbangi atau sejalan konsep bisnis IKNB syariah yang tidak terlepas dari aspek spiritual, tidak hanya orientasi materi tapi juga mencapai kebahagiaan dunia dan akhirat.

\section{DAFTAR RUJUKAN}

\section{Al-Qur'an}

Amin, A. Riawan. 2004. ZIKR, PIKR, MIKR, The Celestial Management. Jakatarta: Senayan Abadi Publishing.

Amalia, Euis.2010 "Peta Potensi SDM Ekonomi Islam Pada PTAI dan PTU: Analisis Kurikulum, Model Pembelajaran dan Hubungannya Dengan Kebutuhan SDM Pada Industri Keuangan Syariah di Indonesia" . Makalah disampaikan pada Forum Riset Perbankan Syaria'ah II 2010, diselenggarakan oleh IPIEF Fakultas Ekonomi UMY, Yogyakarta.

Ismanto, Kuat. 2009. ManajemenSyari'ah Implementasi TQM dalam Lembaga Keuangan Syari'ah. Cetakan Pertama. Yogyakarta: Pustaka Pelajar.

Muhammad. 2003. Kualifikasi Sumber Daya Manusia di Lembaga Keuangan Syariah. Jurnal Hukum Islam Al-Mawarid. Edisi X. Yogyakarta: Fakultas Ilmu Agama Islam UII.

Piliyanti, Indah.2007. Penerapan Konsep The Celestial Mangement (Studi Pada Bank Muamalat Cabang Yogyakarta), Tesis Magister Studi Islam,, Yogyakarta:UII.

Rivai, Veitzhal. 2009. Islamic Human Capital Dari Teori ke Praktik Manajemen Sumber Daya Manusia Islami. Jakarta: Rajawali Press.

Siagin, Sondang P. 2004. Manajemen Sumber Daya Manusia. Jakarta: Bumi Aksara. Otoritas Jasa Keuangan, Roadmap IKNB Syariah 2015-2019

$w w w . k e u a n g a n s y a r i a h m y s h a r i n g . c o m$

www.ojk.go.id

www.kontan.com

www.beritasatu.com 